\title{
URARTIAN RED BURNISHED POTTERY FROM DIYYARBAKIR MUSEUM
}

Oya SAN

\begin{abstract}
Özet
Urartu Krallığı sadece organize devlet yapısı, gelişmiş mimarisi, sulama kanal sistemi ve üstün nitelikli maden işçiliği ile değil madeni kaplara öykünen kırmızı perdahlı seramiği ile de kendisinden söz ettirmektedir. Urartu çömlekçileri bu tür seramiği üretirken özellikle astar ve perdahına önem vererek kapları çekici hale getirdikleri gibi, madeni kap görüntüsünü hissettirmeyi de başarmışlardır. Uzman çömlekçiler tarafından çarkta biçimlendirilen seramiklerin hamurları elenmiş kilden bazen ince kum katılarak hazırlanmıştır. Yoğun olarak kırmızı ve tonlarında olan astarları kapların üzerine firınlamadan önce uygulanmıştır. Oldukça iyi perdahlanan kapların görünümleriyle madeni kaplardan farklı olmadığı anlaşılmaktadır. Tüm Urartu tarihi boyunca kullanıldığı bilinen bu seramiğin çevre kültürler üzerinde etkili olmadığı krallığın yıkılışı ardından ise ortadan kalktığı görülür.
\end{abstract}

Urartu Krallığının kapsadığı geniş coğrafyada benzer form ve yapım teknikleriyle karşımıza çıkan ve uzunca bir süre yoğun olarak kullanılan kırmızı perdahlı Urartu seramiğinin kaliteli örnekleri çalışmaya konu olan ve satın alma yoluyla Van Bölgesinden gelen Diyarbakır Müzesi örnekleri arasında da bulunmaktadır.

Tanıtılan toplam 14 adet vazo farklı formlarda olup tipik Urartu malları durumundadır ve formlar Kaseler (Lev. Ia-b; IIa), Tabak (Lev. IIb), Ayakl Kadehler (Lev. IIIa-b), Yonca ağızlı testiler (Lev. IVa-b; Va), Tek kulplu vazo (Lev. Vb), Çömlekler (Lev. VIa-b; VIIa) ve Ufak çömlek (Lev. VII-b)'den oluşmaktadır.

Diyarbakır Müzesinde yer alan ve çalışmaya konu edilen ondört Urartu seramiği her ne kadar buluntu yerleri ve durumları bilinerek kesin tarihlenemese de araştırmalarla ortaya çıkartılan diğer kırmızı perdahlı seramiklere çeşitlik katmakta ve hatta örneklerine az rastlanan formlara katkıda bulunmaktadır.

\begin{abstract}
Urartian Kingdom has not only become known by its organized state structure, advanced architecture, irrigation system, superior quality metal workmanship but also has become known by its red burnished potteries, which imitate metallic pots. Potteries' pastes, which were given shape at paddle wheels by expert potters, were prepared by using very well sieved clay and sometimes by using additive small piece of sand. Slip, which were usually red and tones of red, were applied before drying in the kiln. The other operation that was realized before the stage of drying in the kiln was burnishing. After a good quality drying, possibly by getting polished with a soft material like leather, their surfaces were provides even and smooth and therefore, there was not any difference in the apparition of the metallic pots. It is known that this pottery was used during whole Urartian history, as well as there was not any pioneer of this pottery, before Urartian Kingdom in the region, and it is known that it was vanished after the collapse of the Kingdom.
\end{abstract}

The good quality samples of the red burnished Urartian pottery that was encountered in similar forms and producing techniques and was used intensely for a long period of time in the large area that was spread by 
Urartian Kingdom, found among the samples, which are subject to the article, and found in the Museum of Diyarbakır, where they had reached there through the purchase that were done with Van Region.

The total of 14 vessels that are introduced, have different shapes and they are typically an Urartian manufatures. Forms are composed from Bowls (Pl. Ia-b; IIa), Plate (P1.IIb), Stemmed Goblets (Pl. IIIa-b), Trefoil Jugs (P1. IVa-b; Va), Single Handled Cup (Pl. Vb), Jars (P1. VIa-b; VIIa) and Small Jar (P1.VIIb).

Fourteen Urartian pots that are included in this work, although their exact places, statuses and dates are unknown, enrich other red burnished potteries came into light until now and even contribute to rarely known form.

Urartian Kingdom that had begun to exist since the second half of the eighth century B.C. in East Anatolia, in the course of time had gained power by spreading through a very wide area of Northwest of Iran, Transcaucasia, Southeast Anatolia and Urartian Kingdom has not only become known by its organized state structure, advanced architecture, irrigation system, superior quality metal workmanship but also has become known by its red burnished potteries, which imitate metallic pots.

Urartian potters, while producing this kind of potteries, as well as making these pots attractive by considering, particularly the burnish and the slip were successful in causing to perceive as metallic pots. ${ }^{1}$ Potteries' pastes, which were given shape at paddle wheels by expert potters, were prepared by using very well sieved clay and sometimes by using additive small piece of sand. ${ }^{2}$ Slip, which were usually red and tones of red, were applied before drying in the

I would like to express my thanks to N. İnal, Director of the Diyarbakır Museum for his permission, to N. Soyukaya and Ş.Yumruk, for their help.

1 Van loon 1966, 32; According to Lehmann-Haupt slip was made of crushed vessels dissolved in water (Lehmann-Haupt, Armenien einst Jetzt, II/2, Berlin, 1910-1931, 577).

2 Emre 1969, 292. The discovery of a potter's wheel at Karmir Blur has been known (see. H.H. von der Osten, Die urartaische Töpferei aus Van und die Möglichkeiten ihrere Einordnung in die Anatolische Keramik I, Orientalia 21 (1952), 310) kiln. The other operation that was realized before the stage of drying in the kiln was burnishing. After a good quality drying, possibly by getting polished with a soft material like leather, their surfaces were provides even and smooth and therefore, there was not any difference in the apparition of the metallic pots. ${ }^{3}$

Red burnished pottery was made in diversity of forms, among the most common Jug with single handle and trefoil rim, stemmed goblets, deep and shallow bowls, plates with sharp or "S" profile rims, storage jars with wide mouths. Miniature versions of these forms were also made in considerable quantities ${ }^{4}$. Some of the vessels that were usually left smooth without any decoration have horizontal groove under the rims. Sometimes, not quite often though, the embossed ornaments were placed on the surface of the pots. Sometimes the vessels were stamped while still damp before firing, on the underside or edge of the base, on the body or handle. There is usually incised decoration consisting of plants, geometric motifs, towers, stars, crescent, or small circles on the handles or where the handles join the body. Such signs were done pottery workshops and were called as potter's mark. ${ }^{5}$

\footnotetext{
3 Van Loon 1966, 30; Emre 1969, 280; Çilingiroğlu 1997, 134, 138.

4 Van loon 1966, 34, Çilingiroğlu 1997, 138.

5 Derin 1999, 81.
} 
This type of pottery had been used by a class whose members are mostly Urartian and probably, the public or other people from different regions that are not Urartian had used this pottery less than Urartians ${ }^{6}$. In addition to that, the recent excavations at Urartian Fortresses and cemeteries show that this pottery was utilized as daily wares, as burial gifts in the cemeteries, and as a good, people used them for their wishes as a votive and left them in the temples. This situation indicates the diversity of the functions of pots and their usage purposes.

Formerly the red burnished pottery was called "Toprakkale Ware" by Burney, due to the large amount of it was discovered, in Toprakkale ${ }^{7}$. In the first period of time, when Van Fortress was excavated, term of "Vannic Sherds" was used". While Kroll believes the most appropriate term for this pottery was "Palastware", lastly Tarhan and Sevin preferred to use "Bianili Ceramics" term, which is nowadays used widely for this pottery that was produced in the fortresses, which were established by central governments. $^{10}$

It is known that this pottery was used during whole Urartian history, as well as there was not any pioneer of this pottery, before Urartian Kingdom in the region ${ }^{11}$, and

6 Çilingiroğlu 1997, 134.

7 Burney 1957, 42. Urartian red burnished pottery has been being discussed since the last quarter of the nineteenth century (see. H.H. von der Osten, Orientalia 21, 308) But until the excavations undertaken by K. Lake at Van, this subject did not reach the stage of serious investigation. From the Second World War onwards research on Urartian pottery has considerably developed and excavations at the Urartian sites have increased our knowledge of the pottery.

8 Tarhan-Sevin 1991, 432.

9 Kroll 1976, 9.

10 Tarhan-Sevin 1976-77, 292.

11 Von der Osten has pointed out the resemblence between Hittite and Urartian pottery. Because there it is known that it was vanished after the demolishment of the Kingdom ${ }^{12}$. Although the excavations and the surveys indicate that this pottery was utilized mostly at Van Lake District ${ }^{13}$, it is known that it was produced in every area that was in the kingdom's sovereignty. This pottery was produced, especially under the supervision of the government, at the pottery workshops with a uniform, in respect to quality, form and decoration and the potteries that were discovered in Urartian fortresses, houses, and cemeteries are similar in terms of appearance and technique ${ }^{14}$. At the same time, instrumental neutron activation analysis that was applied on the Urartian potteries, which were obtained from various centers, provides information about the production of the pottery. Results of the analysis show that this type of pottery was produced in many centers of Urartian Kingdom and traded between the Urartian centers, and come into the light that even, there was a trade of pottery between Van Region and Northwest of Iran. ${ }^{15}$

The good quality samples of the red burnished Urartian pottery that was encountered in similar forms and producing techniques and was used intensely for a long period of time in the large area that was spread by Urartian Kingdom, found among

is a similarity in the slip and the polish application tecnique (see. H.H. von der Osten, Orientalia 21, 314). But Hittite pottery was not used in Central Anatolia later than 1200 B.C. According to Emre "the similarity between Urartian and Hittite pottery in slip and gloss technique should be attributed to their common roots, that is, adherence to the old native Anatolian tradition" (Emre 1969, 298). On the other hand Bittel writes that the Hittite tradition could have passed on to the Urartians through the Hurrrian (see. K.Bittel, Gründzüge der vor Frühgeschichte Kleinasiens. 2. Auflage (1952), 80).

12 Emre 1969, 288; Çilingiroğlu 1997, 134.

13 Çilingiroğlu 1997, 134.

14 Emre 1969, 289.

15 Speakman et.al. 2004, 119, 126. 
the samples, which are subject to the article, and found in the Museum of Diyarbakır, where they had reached there through the purchase that were done with Van Region.

The total of 14 vessels that are introduced, have different shapes and they are typically an Urartian manufatures. Forms are composed from Bowls (Pl. Ia-b; IIa), Plate (P1.IIb), Stemmed Goblets (P1. IIIa-b), Trefoil Jugs (Pl. IVa-b; Va), Single Handled Cup (Pl. Vb), Jars (Pl. VIa-b; VIIa) and Small Jar (Pl.VII-b).

\section{Bowls (PI. Ia-b, IIa)}

One of the most used forms of the Urartian red burnished pottery is bowls that have different forms themselves. Generally, the rims are everted and sometimes there may be a deep groove under the rim. At the same time, metallic bowls that were discovered at the Igdir $^{16}$, Altintepe ${ }^{17}$ and Karmir Blur excavations and which were probably used at the cult rituals have the similar forms of ceramic ones and therefore, it indicates that that kind of bowls were inspired and produced from this type of metallic models ${ }^{18}$.

Bowls, which are studied, are represented by three samples. First one (Pl. Ia) attracts the attention with its simple form. Bowl's rim is everted slightly and body, as becoming narrow downwards, sits on a flat base. On the surface of the pinkish buff fabricated, a dark orange, red slip and dense burnish can be identified. The similar forms of these potteries, which are known to be manufactured in large numbers in the Urartian pottery repertoire $^{19}$, could be met in

16 Barnett 1963, 166; Fig. 23.1-3.

17 Emre 1969, 282.

18 Savaş ve Estetik 2004, 268.

19 Kroll 1976, 115, Type 13a.
Van Fortress ${ }^{20}$, Ayanis $^{21}$, Van-Altıntepe ${ }^{22}$, Erzincan-Altıntepe ${ }^{23}$, Bastam ${ }^{24}$ and Armavir Blur ${ }^{25}$.

The second sample of the group is formed by a bowl, which is thick and which has an everted rim, rounded body, and flat base (Pl. Ib). Pinkish buff fabricated bowl's slip color is dark red and burnish marks, which are inside and outside of the bowl, are clear. Van Fortress $^{26}$, Erzincan Altintepe ${ }^{27}$, and Argiştihinili ${ }^{28}$ are the Urartian settlements that have the similar samples of this group ${ }^{29}$.

The last bowl sample is differentiated from the others with its symetrical small vertical handle (Pl. IIa). Under rim of the bowl, which has a simple rim, there is a deep groove. The wide and oval body sits on a flat base downwards. The bowl's paste, which has a deep red paste structure, has the same color slip with its paste and on the surface; a pale burnish could be seen. In addition to that, the color waves, caused by drying in the kiln could be identified on the surface. Those bowls and similar bowls that were evaluated by Kroll, within Type 156, do not have much place in the Urartian red burnished pottery ${ }^{30}$. At the same time, although it does not have a handle, a bowl that has the same form with its groove, under the rim was founded at Van Fortress $^{31}$. Another bowl sample, which is pale burnished with grooved rims and handles, is met at Çavuştepe ${ }^{32}$. Çavuştepe

20 Tarhan-Sevin 1991, Fig. 19: 2-3; Sevin 1994, Fig. 21: 4.3; Tarhan 1994, Fig. 22.3;

21 Çilingiroğlu-Derin 1998, Fig. 9.

22 Sevin et.al. 2000, Fig. 6.1.

23 Emre 1969, Pl. II.3.

24 Kroll 1970, Pl. 3.9.

25 Barnett 1963, Fig. 19.

26 Tarhan-Sevin 1991, Fig. 19.6.

27 Emre 1969, P1. II. 2.

28 See. A. A. Martirosjan, Argiştihinili (1974), Fig. 66.

29 Kroll 1976, 119, Type 23.

${ }^{30}$ Kroll 1976, 117, Type 156.

31 Tarhan 1994, Fig. 23.4.

32 Erzen 1978, Fig. 36/7. 
sample, which is from seventh century B.C., attracts the attention with its vertical handle, which is wider than the sample we have identified above. The sample, we have examined and which have entered to the Urartian red burnished pottery group, with their characteristics of slip, burnish and form, is the representative of a form that is not seen often with its handle structure.

\section{Plate (PI. IIb)}

One of the forms that was largely manufactured as bowls in Urartian red burnished pottery is plates ${ }^{33}$. With their shallow bodies, smooth and circular bases, smooth and everted rims, these plates have very simple forms. Among the identified potteries only one plate represents this group (P1. IIb). The plate that has lightly everted rim is quite shallow and has a concave base. The plate that has a pinkish buff fabric and red burnish was burnished inside and outside, densely. It may be said that, as with the bowls, these kinds of plates have metallic samples and they were inspired from these metallic bowls ${ }^{34}$. For example, the plate that was from Çavuştepe and dated to second half of the seventh century B.C. resembles to the sample we have defined with its form and it also reminds the metallic pots with very careful workmanship and dense burnish ${ }^{35}$.

\section{Stemmed Goblets (PI. IIIa-b)}

The basic characteristics of the stemmed goblets, which are sometimes big, sometimes small in sizes, are their high and hollow stands. Goblets, which are one of the red burnished pottery's typical forms, may be seen in most of the Urartian settlements with

33 Kroll 1976, 122, Type 32.

34 Barnett 1963, 166.

35 Erzen 1978, Fig. 30; Pl. XXXIX.d. similar form characteristics ${ }^{36}$. Two samples, related to this form, are mentioned in this study. The first one attracts the attention with its big size (P1. IIIa). Goblet, with everted rim, wide cylindrical neck, global body and which sits on the high and hollow stand, has a broken base. Pinkish buff fabricated, dark red slipped and dense burnished goblet has a relief band on the shoulder. The second example has the similar characteristics with the former one, although its length is shorter (P1. IIIb). Goblet, which has a protected wide base cut, attracts the attention with its pinkish buff fabric, red and dense slip. It is observed that the Erzincan-Atıntepe sample of such goblets, which were found in many Urartian settlements, in different sizes and similar forms, are left as a votive object in the cella of the temple ${ }^{37}$. This shows us that in Urartian Kingdom, potteries were also used them as votives along with the metal objects. In addition to Altıntepe sample, Adilcevaz $^{38}$, Toprakkale ${ }^{39}$, Van- Altıntepe ${ }^{40}$, Kayalıdere $^{41}$, Çavuştepe ${ }^{42}$, Karmir Blur ${ }^{43}$ and Van Museum ${ }^{44}$ samples, give us the information regarding the widespread use of goblets within Urartian Kingdom.

\section{Trefoil Jugs (PI. IVa-b; Va)}

Trefoil jugs also have their place within the forms of vessels belonging to the Urartian red burnished pottery ${ }^{45}$. Although they are slightly different from each other with their miniature and large sizes, the characteristic of trefoil rims is common

\footnotetext{
${ }^{36}$ Kroll 1976, 129, Type 47a.

37 Emre 1969, 5, 284, Fig.19; Pl. XXXIII, 3, Fig.7.

38 Öğün-Bilgiç 1967, 165.

39 See. Lehmann-Haupt, Armenien einst Jetzt, II/2, Berlin, 1910-1931, 567.

40 Sevin et.al. 2000, Fig.4.

41 Burney 1966, Pl.XVb, Fig. 15.

42 Erzen 1976, Fig.3.

43 Piotrovsky 1955, Fig.9.

44 Savaş ve Estetik 2004, 141.

45 Kroll 1976, 128, Type 46.
} 
among them without exception. The fact that trefoil jugs, which came into life in Anatolia, third millenium B.C. and reappeared in Iron Age in Urartian Kingdom, found in clusters inside the Karmir Blur state warehouse, shows that trefoil jugs were extensively used and produced within the Urartian Kingdom $^{46}$. The researches done until now showed that the same forms could be found within the metal samples, especially bronze ones. This proves that trefoil jugs are also inspired from the metal pieces ${ }^{47}$. Although the surface of the most of them are burnished and does not have any decoration, there are vessels that have embossed long tongue shaped decorations ${ }^{48}$. Founding conditions and Urartian reliefs show that such jugs were used for carrying and pouring water and as burial gifts and urns in the graveyards, and votives $^{49}$ within the temples and as ritual objects for the cult ceremonies ${ }^{50}$.

The first sample of the trefoil jug, we have mentioned above, is larger than the other samples (P1. IVa). The pot with a trefoil rim, round body and flat base, has an embossed band under its neck and a groove on its handle. Those properties make them even more similar to the metal samples. The jug has pinkish buff fabric, high quality dark red slip and dense burnish on the surface. Although the second one is in smaller size, it has almost the same decorative and form properties with the former sample and has the same quality fabric, slip and burnish, as if they were made by the same hand (Pl. IVb). Although the body of the third trefoil jug has an oval shape, its rim, handle and base form makes it a variation of the same type of jugs and its pinkish buff fabric color,

46 Piotrovsky 1955, Pl. VII.

47 Piotrovsky 1955, Fig. 13.

48 Savaş ve Estetik 2004, 136.

49 Emre 1969, 283.

50 Depictions of Urartian cult ceremonies show similar jugs being used (Çilingiroğlu 1997, 102; Fig.21). dark red slip and dense burnish are the most important features (Pl. Va) .

As a result of the surveys and excavations, up until now, it is understood that although known samples from centers such as the Van Fortress ${ }^{51}$, Toprakkale ${ }^{52}$, Çavuştepe $^{53}$, Van-Altıntepe ${ }^{54}$, Ayanis $^{55}$, Adilcevaz $^{56}$, Iğdır ${ }^{57}$, Erzincan- Altıntepe ${ }^{58}$, Karmir Blur ${ }^{59}$, Armavir ${ }^{60}$ and Bastam ${ }^{61}$ have some differences in their forms, they point out the extensive usage of trefoil jugs in the Urartian civilization with their similar features of trefoil jugs.

\section{Single Handled Cup (Pl. Vb)}

The pot, which is represented with a single sample, is a typical Urartian production with its red dense burnish and pinkish buff fabric. However, when it is examined according to its form, we soon realize that it is an extraordinary piece (P1. $\mathrm{Vb})$. The vase with flat rim, cylindrical wide neck, that sits on a flat base diving below, has a single handle passing over its rim and joining with the edge of its shoulder. Although we may not find many similar pieces with the defined form properties within Urartian red burnished potteries, the double handled Urartian jar, found in Bastam, and shows us with a very similar form ${ }^{62}$.

\footnotetext{
51 Tarhan-Sevin 1991, Fig. 20:1; Sevin 1994, Fig. 21.3; 3-4.; Tarhan 1994, Fig. 25.1.

52 Erzen et.al. 1960, 17, Fig. 20, 21.

53 Erzen 1976, Fig. 4; 1978, Pl. XLIIa-b, Fig. 37-1,2.

54 Sevin et.al. 2000, Fig. 6: 5,6.

55 Derin 1999, Fig. 6:44, 54, 71.

56 Öğün 1967, Fig. 17.

57 Barnett 1963, Fig. 20.2.

58 Emre 1969, P1.III, Fig. 18.

59 Piotrovsky 1952, Fig.15-16; 1955, Pl. VII; 1969, 49-50; 1970, Cat. 117; Barnett-Watson 1982, Fig.16.

60 See. A. A. Martirosjan, Argiştihinili (1974), Fig. 4,5 .

${ }^{61}$ Kroll 1970, Pl. 1,2, 1.7;26.

${ }^{62}$ Kroll 1970, Pl. 5.3.
} 


\section{Jars (PI. VIa-b; VIIa-b)}

Jars of different sizes and forms make up the last group of pieces, found in the Diyarbakir Museum and are represented by four samples.

The first sample of the group is the Oval bodied cremation Jar (Pl. VIa), which has buff fabric, light red slip and pale burnish, an everted rim, short cylindrical neck, oval body and a flat base. There are two embossed bands within the transition from the bottom of the neck to shoulder and two adjacent holes, which indicate that this piece was used for the cremation purposes, as urns to be more specific ${ }^{63}$. These forms and decorations, which Kroll regards as they belong to Type $49^{64}$ and Derin regards as they belong to $\mathrm{Ba}$ group $^{65}$, are used frequently as urns and burial gifts in cemeteries and storage jars in daily life.

These types of urns were generally buried inside the niches, rock cracks or directly under the ground and as burial gifts were left inside of and near $i t^{66}$. In addition, we see that the mouths of the urns are closed with a plate or bowl for preservation ${ }^{67}$. Extensive variety of urn samples found in centers such as the Van Fortress ${ }^{68}$, Van-Altıntepe ${ }^{69}$, Dil$\operatorname{kaya}^{70}$, Kalecik ${ }^{71}$, Adilcevaz ${ }^{72}$, Habibuşağ ${ }^{73}$,

63 The Holes in the urns show an important feature. Cremation burials were usually placed in urns which had a hole or holes (Derin 1994, 50).

${ }^{64}$ Kroll 1976, 130, Type 49.

${ }^{65}$ Derin 1994, Fig. 6.2.2; 6.3.

${ }^{66}$ Usually the metal objects such as arrow head, belts etc. were crushed and left beside the urns or were broken and put in the urns with the ashes and crumbled bones (Barnett 1963, 153)

67 Barnett 1963, 153; Derin 1994, 49.

${ }^{68}$ Sevin 1980, 151.

${ }^{69}$ Sevin 2000, 424, Fig. 4; Sevin-Özfirat 200, 219, Fig. 6.

70 Cilingiroğlu 1991, 29.

71 Öğün 1978, 672.

72 Öğün 1974, 448.

73 Iş1k 1987, 551, 562.
Kayalıdere $^{74}$, Erzincan-Altıntepe ${ }^{75}$, Patnos ${ }^{76}$, $\mathrm{Liç}^{77}$, Kars Arpaçay ${ }^{78}$, Iğdır ${ }^{79}$, Nor Areş ${ }^{80}$, Arin Berd ${ }^{81}$, Alişar ${ }^{82}$, Argiştihinili ${ }^{83}$ and in Van and Elazig Museums ${ }^{84}$ within the wide geography of Urartian Kingdom, shows us that this burial form is as wide spread as inhumation burial form.

Second sample is the Round Bodied Jar (Pl. VIb). The vessel with an everted rim, low cylindrical neck, and asymmetrical round body sits on a flat and straight base. As in the previous example, there is a wide relief band from neck to shoulder of the jar. The vessel, which has a buff fabric, has light reddish partially waving slip and a dense burnish on the surface. It is also known that bronze samples of the ceramic potteries of the same form (Pl. VIa-b, VIIa) also exist. They are similar in form and they have holes on the shoulder regions as their ceramic counterparts ${ }^{85}$. As a result, it can be stated that these types of potteries are produced, imitating the metal samples, as in the case of other forms.

The last sample for big sized jars is again a Round Bodied Jar (Pl. VIIa). However, this one is different with its decorative properties (P1. VIIa). The jar, which has an everted rim that has grooves on, long neck, round body and flat base, has buff fabric, red slip and dense burnish on the surface. On the shoulder, there are dangling triangles, which are filled with the round patterns on the inner

74 Burney 1966, 107.

75 Emre 1969, 280; Özgüç 1969, 15.

76 Öğün 1978, 668.

77 Öğün 1978, 648.

78 San 2003, 2, Fig. 2.

79 Barnett 1963, 155-156.

80 Barnett 1963, 153.

81 Piotrovsky 1964, 94.

82 Öğün 1974, 448.

${ }^{83}$ See. A.A. Martirosjan, Argishtihinili (1974) Fig.14, III, 52.

84 Derin 1994, 49-62.

85 Barnett-Gökçe 1953, 124; Klein 1977, 87-88. 
edges, within a $3 \mathrm{~cm}$ band. Moreover, the color differences established via slipping the insides of the triangles with a lighter color attracts the attention. We may see that in Urartian Pottery decorations on such jars are rarely $\operatorname{seen}^{86}$. For example, we may see a similar decoration on the shoulder edge of an urn found in the rock cracks in Igdir ${ }^{87}$; and, on another sample coming from KarsArpacay, we may see a decoration field consisting of dangling triangles hatched from inside $^{88}$.

The fact that there are no holes on the last two samples, we have discussed here, causes suspicions on their use for the cremation purposes. Although there are urns with no holes on them in Urartians, we are unable to come into a conclusion on their exact usage, as we do not have enough information regarding their foundling states. Therefore, the vessels may be used as urns, but they as may be used as daily storage vessels.

\section{Round Bodied Small Jar (PI. VIIb)}

A rather small pot sample is the last example within the group (Pl. VIIb). With an everted rim, low cylindrical neck, asymmetrical round body; the pot sits on a flat and straight base. The vessel contains all the properties of a typical red burnished Urartian pottery with pinkish buff fabric, dark red smooth slip and dense burnish. Although, it looks like the urn style vessels, it is much smaller in size and there is no information found yet, proving the usage of a vessel of this size as an urn. On the other hand, the fact that there are no same pots found in the region show us the rare use of such vessels in Urartu. However, we may

86 Derin 1994, Fig. 6.3.23.

87 Barnett 1963, Fig. 14.11.

${ }^{88}$ San 2003, Fig. 2. find only one similar sample within the ceramics found in Bastam ${ }^{89}$.

Red burnished Urartian pottery, which had become a symbol for Urartu, from the establishment to the declination of the Urartian Kingdom, is a product of Urartian royal art. As in the case of other Ancient Near East Civilizations, royal arts of Urartu followed predetermined styles and traditions and as a result, the ceramics resembled the products of the same form and techniques; and therefore they played a binding role between the communities under the management of the central authority. Those ceramics, produced in specific workshops with similar forms, also shows the conservative approach to this art; the reason for that is, although they had given the opportunity to ceramic artists to express their abilities, the fact that the same form was used without any change for centuries, proves their conservativeness. Their high competency in metal work encouraged them to produce pieces, imitating metal works, using ceramics. However, those vessels, which were highly appealing for the eye, did not have any effect on the nearby cultures and disappeared after the collapse of the kingdom. In conclusion, fourteen Urartian pot that are included in this work, although their exact places, conditions and dates are unknown, enrich other red burnished potteries came into light until now and even contribute to rarely known form.

\section{Yrd.Doç.Dr.Oya SAN}

Dicle Üniversitesi Fen Edebiyat Fakültesi, Arkeoloji Bölümü, DIYYARBAKIR oyasan@dicle.edu.tr

89 Kroll 1970, P1. 5.5. 


\section{Catalog of Illustrated Pottery}

Abbreviations used: RD (Rim Diameter), BD (Base Diameter), H (Height) All measurements are in meters.

\section{Plate Ia}

Bowl

RD. 15; BD. 2.5; H. 5.5

Wheel made; pinkish buff fabric; dark orange red slip; brightly burnished; wellfired.

Diyarbakır Museum Inv No: 26/30/76.

\section{Plate Ib}

Bowl

RD. 13; BD. 4; H. 4.2

Wheel made; pinkish buff fabric; dark red slip; brightly burnished; well fired.

Diyarbakır Museum Inv No: 11/11/97.

\section{Plate IIa}

Bowl with Vertical Handle

RD. 13; BD. 4.5; H. 6

Wheel made; dark red fabric; dark red slip; pale burnished; well fired.

Diyarbakır Museum Inv No: 17/9/82.

\section{Plate IIb}

Plate

RD. 14; BD. 2.8; H. 3

Wheel made; light red fabric; red slip; brightly burnished inside and out; well fired.

Diyarbakır Museum Inv No: 5/8/77.

\section{Plate IIIa}

Stemmed Goblet

RD. 13.5; BD. 7 (broken); H. 31

Wheel made; light red fabric; dark red slip; brightly burnished; well-fired.

Diyarbakır Museum Inv No: 13/67/77.

\section{Plate IIIb}

Stemmed Goblet

RD. 8; BD. 6; H. 18.5

Wheel made; light red fabric; red slip; brightly burnished; well fired.

Diyarbakır Museum Inv No: 6/2/77.

\section{Plate IVa}

Trefoil Mouthed Jug

RD. 7.5; BD. 6.5; H. 31
Wheel made; light red fabric; dark red slip; brightly burnished; well fired.

Diyarbakır Museum Inv No: 5/3/77.

\section{Plate IVb}

Trefoil Mouthed Jug

RD. 3.5; BD. 3.9; H. 12.5 .

Wheel made; pinkish buff fabric; dark red slip; brightly burnished; well fired.

Diyarbakır Museum Inv No: 4/196/2000.

\section{Plate Va}

Trefoil Mouthed Jug

RD. 6; BD. 5.5; H. 15.

Wheel made; pinkish buff fabric; dark red slip; brightly burnished; well fired.

Diyarbakır Museum Inv No: 6/4/82.

\section{Plate Vb}

Single Handled Cup

RD. 10.5; BD. 3; H. 10.

Wheel made; pinkish buff fabric; dark red slip; brightly burnished; well fired.

Diyarbakır Museum Inv No: 6/3/77.

\section{Plate VIa}

Oval bodied Cremation Jar (Urn)

RD. 13.2; BD. 10; H. 26.2.

Wheel made; buff fabric; red slip; pale burnished; well fired.

Diyarbakır Museum Inv No: 7/21/86.

\section{Plate VIb}

Round Bodied Jar

RD. 16.5 ; BD. 14; H. 36.5 .

Wheel made; buff fabric; red slip; brightly burnished, well fired.

Diyarbakır Museum Inv No: 9/6/78.

\section{Plate VIIa}

Round Bodied Jar

RD. 13.5; BD. 12.9; H. 26.

Wheel made; buff fabric; orange red slip; brightly burnished; well fired.

Diyarbakır Museum Inv No: 7/4/86

\section{Plate VIIb}

Round Bodied Small Jar

RD. 6; BD. 3; H. 12.

Wheel made; pinkish buff fabric; dark red slip; brightly burnished; well fired.

Diyarbakır Museum Inv No: 16/17/76 


\section{REFERENCES}

Barnett-Watson 1952

Barnett-Gökçe 1953

Barnett 1963

Biscione 1994

Burney 1957

Burney 1966

Burney-Lang 1971

Çilingiroğlu 1991

Çilingiroğlu 1997

Çilingiroğlu - Derin 1998

Çilingiroğlu 2001

Derin 1994

Derin 1999

Işık 1987

Emre 1969

Erzen et al. 1960

Erzen 1976

Erzen 1978

French-Summers 1994

Klein 1974

Kroll 1970

Kroll 1976
R.D.Barnett; W.Watson, "Russian Excavations in Armenia", Iraq XIV, (1952): 132-147.

R.D.Barnett; N.Gökçe, "The Finds of Bronzes at Altıntepe Near Erzincan", AnatStudies, 3, (1953): 153-198.

R.D.Barnett, “Urartian Cemetery at Iğdı»”, AnatStudies, 13, (1963): 178-197.

B.Biscione, "Recent Urartian Discoveries in Armenia: The Columbarium of Erevan”, Studi Micenei ed Egeo-Anatolici, 34, (1994): 115-135.

C.A.Burney, "Urartian Fortresses and Towns in the Van Region", AnatStudies, VII, (1957): 37-45.

C.A.Burney, "A first Season of Excavation at the Urartian Citadel at Kayalıdere", AnatStudies, 16, (1966): 55-111.

C.A.Burney; D.M.Lang, The Peoples of the Hills , Ancient Ararat and Caucasus, (1971).

A.Çilingiroğlu, "The Early Iron Age at Dilkaya" in A. Çilingiroğlu - D.H.French (Eds), Anatolian Iron Age, 2, (1991): 29-38.

A.Çilingiroğlu, Urartu Krallı̆̆ Tarihi ve Sanatı, (1997).

A.Çilingiroğlu; Z.Derin, “Ayanis Kalesi Kazıları-1996”, 19.KST-I , (1998): 591606.

A.Çilingiroğlu; M.Salvini (Eds), "Ayanis I: Ten Years. Excavations at Rusahinili Eidurukai 1989.1998", CNR Istituto pergli Studi Micenei ed Egeo-Anatolici, Roma, (2001).

Z.Derin, "The Urartian Cremation Jars in Van and Elazı̆ Museum, in A.Çilingiroğlu-D.H.French (Eds), Anatolian Iron Ages, The Proceeding of the Third Anatolian Iron Ages, Colloquim held at İzmir 4-8May 1990, (1994): 49-62.

Z.Derin, "Potters Marks of Ayanis Citadel, Van",in A.ÇilingiroğluR.J.Mathews(Eds), Anatolian Iron Ages, The Proceeding of the fourth Anatolian Iron Ages , Colloquim held at Mersin,19-23 May 1997, AnatStudies 49, (1999): 81100.

C.Işık, “Habibuşağı Nekropolü”, Belleten, 200, (1987): 549-580.

K.Emre, “Altıntepe'de Urartu Seramiği”, Belleten, XXXIII/131 (1969): 280-301.

A.Erzen; Y.Boysal; B.Öğün, “1959 Toprakkale Sondajları”, Türk Arkeoloji Dergisi, $\mathrm{X}-1,(1960)$ :

A.Erzen, "Van Bölgesinde Yeni Urartu Araştırmaları", TürkTK VII/1, (1976): 251262.

A.Erzen, Çavuştepe I (1978).

D.H.French; G.D.Summers, "Pre-Urartian and Urartian Pottery From the Muş Region”, AnatStudies, XLIV, (1994): 77-84.

J.J.Klein, "Urartian Hieroglyphic Inscriptions from Altıntepe", AnatStudies, 24, (1974): 77-93.

S.Kroll, "Die Keramik aus der Ausgrabungen Batsam 1969", Archaeologische Mitteilungen aus Iran, New Folge Band 3 (1970): 67-85.

S.Kroll, "Keramik Urartaischen Festungen in Iran", Archaeologische Mitteilungen aus Iran, Erganzungsband 2 (1976): 
Öğün-Bilgiç 1967

Öğün 1974

Öğün 1978

Özgüç 1969

Piotrovsky 1952

Piotrovsky 1955

Piotrovsky 1969

Piotrovsky 1970

San 2003

Savaş - Estetik 2005

Sevin 1980

Sevin 1994

Sevin 1999

Sevin-Özfırat 2000

Sevin et.al . 2000

Speakman et al. 2004

Tarhan-Sevin 1976-77

Tarhan-Sevin 1991

Tarhan 1994

Van Loon 1966
B.Öğün; E.Bilgiç, “Adilcevaz Kef Kalesi Kazıları 1967”, TürkAD 16-1 (1967): 4556.

B.Öğün, Urartu Halk Mezarları, Cumhuriyetin 50. Yıldönümü Anma Kitabı (1974): 443-469.

B.Öğün, Die urartaischen Bestatungsbrauche, in Şahin, S. (eds) Studen zur religion und Kultur Kleinasiens, Festschrift fürr F.K. Dörner zum 65. Geburstag am 28 Februar 1976, 2 (1978): 639-678.

T.Özgüç, Altıntepe II, Mezarlar, Depo Binası ve Fildişi Eserler (1969).

B.B.Piotrovsky, Karmir Blur II 1949-1950 (1952).

B.B.Piotrovsky, Karmir BlurIII (1955).

B.B.Piotrovsky, Urartu (1969).

B.B.Piotrovsky, Karmir Blur (1970).

O.San, "Kars Müzesinden Bir Grup Vazo Işı̆̆ında Erken Birinci Binyılda Kars ve Yöresi”, Türk Arkeoloji ve Etnoğrafya Dergisi 3 (2003): 1-10.

Urartu: Savaş ve Estetik (2005).

V.Sevin, "Van Kalesinde Bir Kaya Mezarı ve Urartularda Ölü Yakma Geleneği”, Anadolu Araştırmaları 8 (1980): 151-164.

V.Sevin, "The Excavations at the Van Castle Mound",in Çilingiroğlu-D.H.French (Eds), Anatolian Iron Ages3, The Proceeding of the third Anatolian Iron Ages , Colloquim held at Van,6-12 August 1990, (1994): 221-228.

V.Sevin, "The Origins of the Urartians in the light of the Van/ Karagündüz Exvavations", Ed. A.Çilingiroğlu-R.J.Mathews, Anatolian Iron Ages, The Proceeding of theFourth Anatolian Iron Ages , Colloquim held at Mersin,19-23 May 1997, AnatStudies 49, (1999): 159-164.

V.Sevin; A.Özfırat, "Van /Altıntepe Kazıları", O. Belli (Ed), Türkiye Arkeolojisi ve İstanbul Üniversitesi (2000): 217-222.

V.Sevin; A.Özfirat; E.Kavaklı, “1997-1998 Van/Altıntepe Urartu Nekropolü Kazıları", 21KST-1 (2000): 421-431.

R.J.Speakman; E.C.Stone; M.D.Glascock; A.Çilingiroğlu; P.Zimmansky; H.Neff, "Neutron Activation analysis of Urartian Pottery from Eastern Anatolia", Journal of Radioanalytical and Nuclear Chemistry 262/1, (2004): 119-127.

T.Tarhan; V.Sevin, "Van Bölgesinde Urartu Araştırmaları I: Askeri ve Sivil Mimariye ait Yeni Gözlemler”, AnadoluAraş 4-7 (1976-77): 275-304.

T.Tarhan; V.Sevin, "Van Kalesi ve eski Van Şehri Kazıları", 12 KST/II (1991): 429-455.

T.Tarhan, "Recent Research at the Urartian Capital Tuşpa", Tel Aviv 21/1 (1994): $22-58$.

M.N.Van Loon, Urartian Art, İstanbul, (1966). 
Urartian Red Burnished Pottery From Diyarbakır Museum

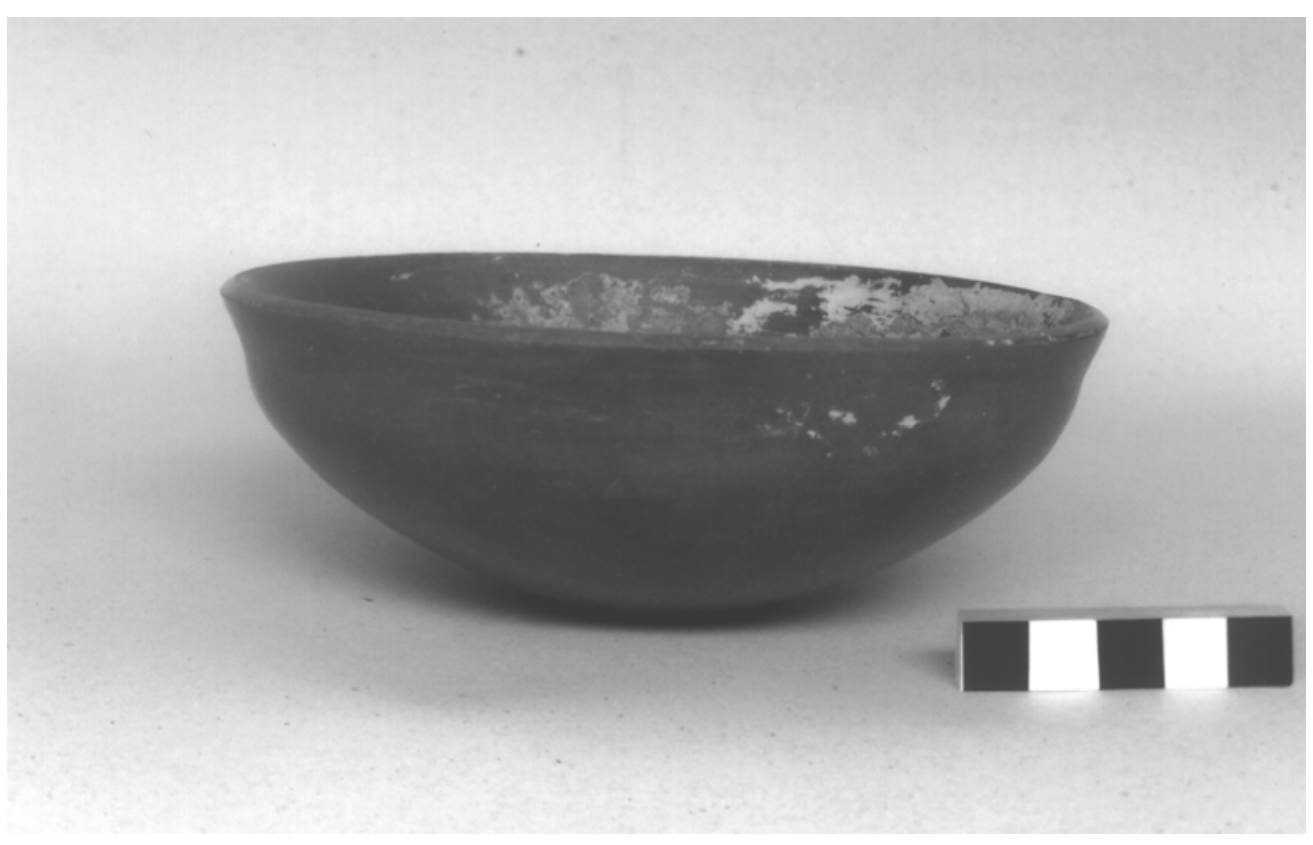

a

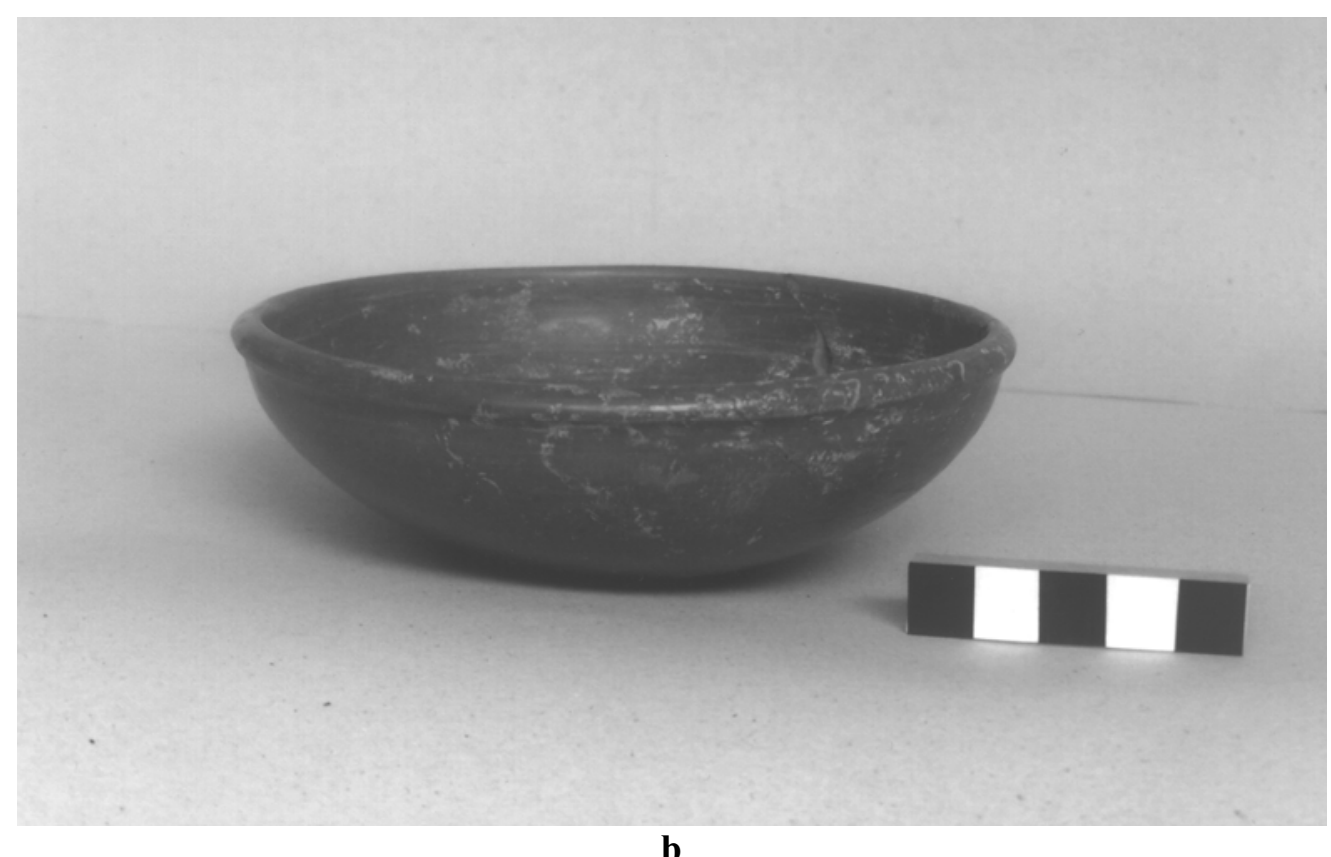

b

Plate I 

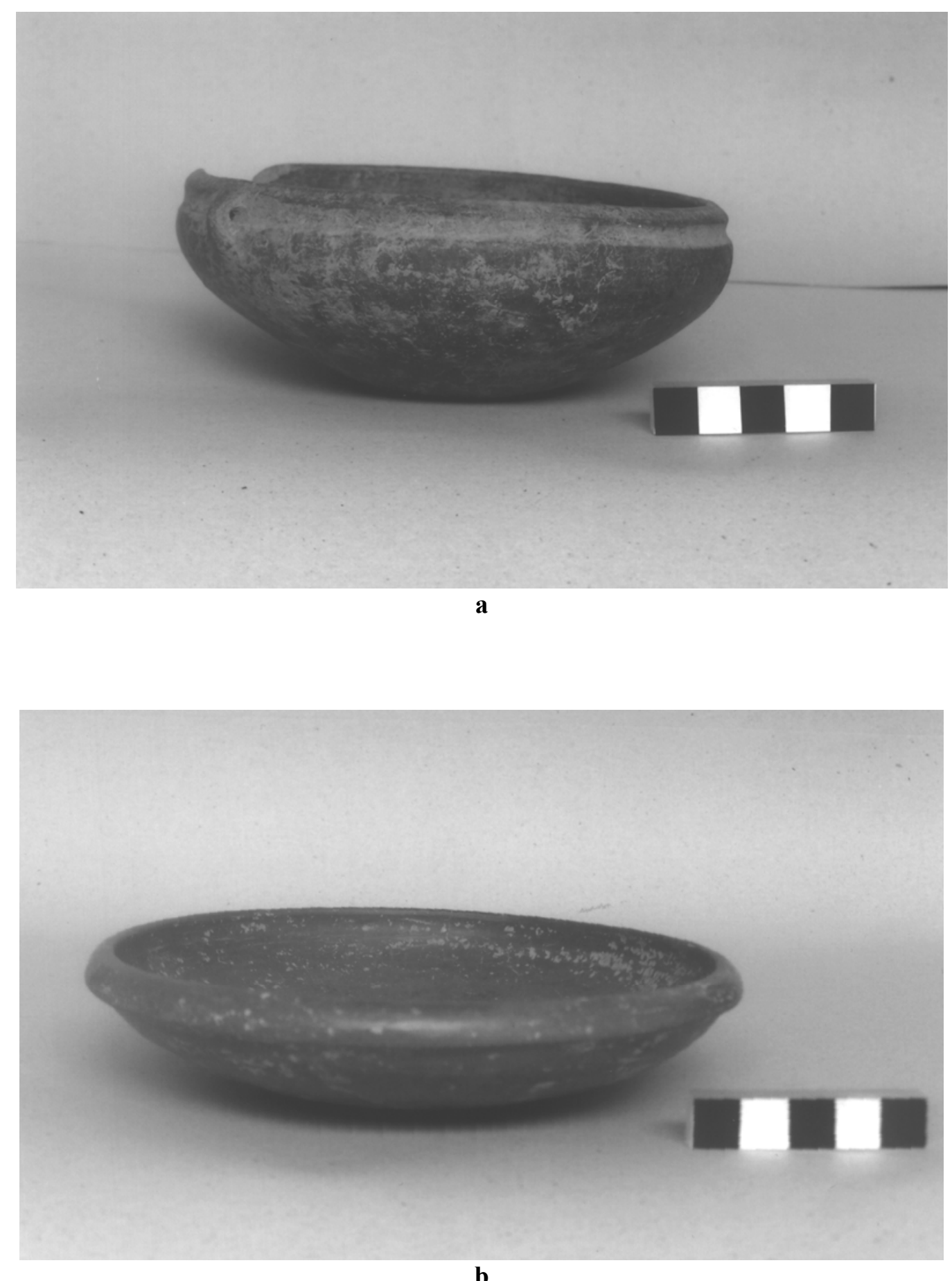

b

Plate II 
Urartian Red Burnished Pottery From Diyarbakır Museum

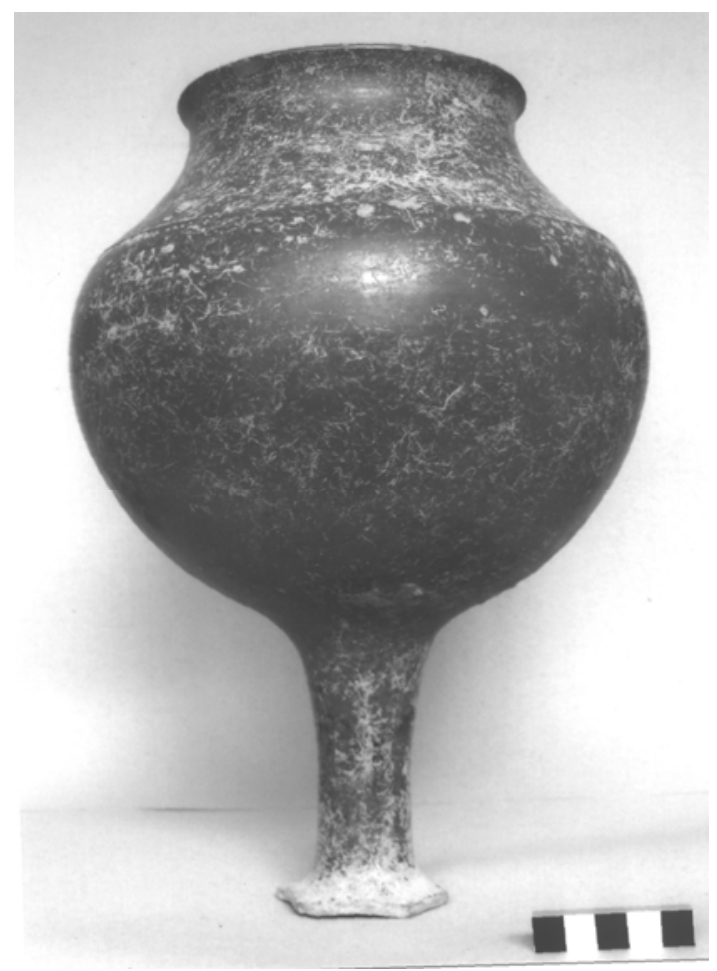

$\mathbf{a}$

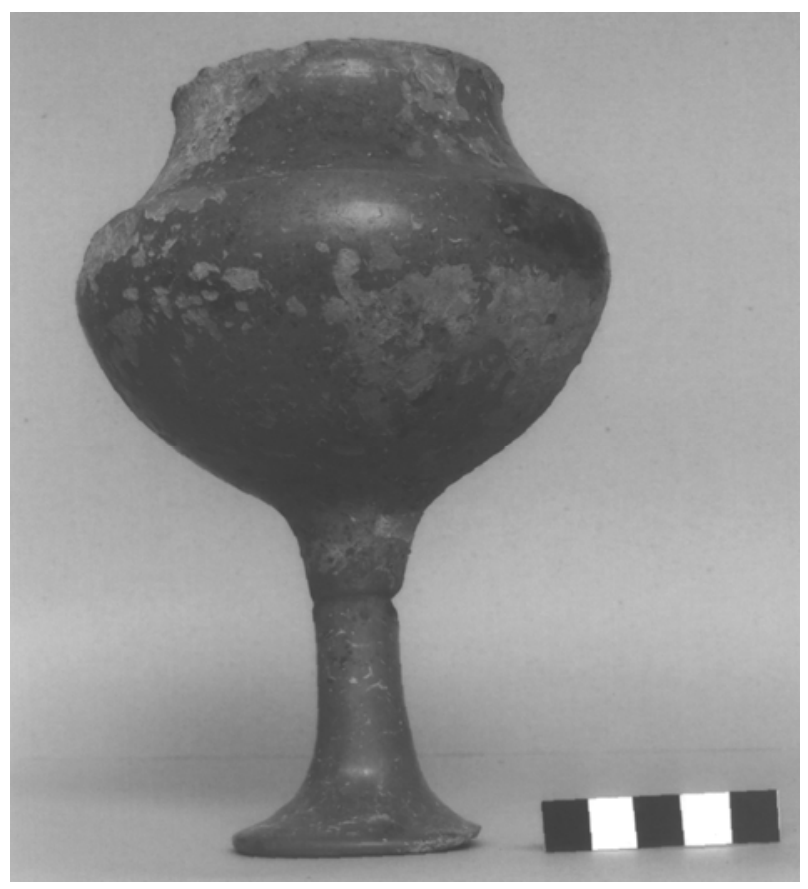

b

Plate III 


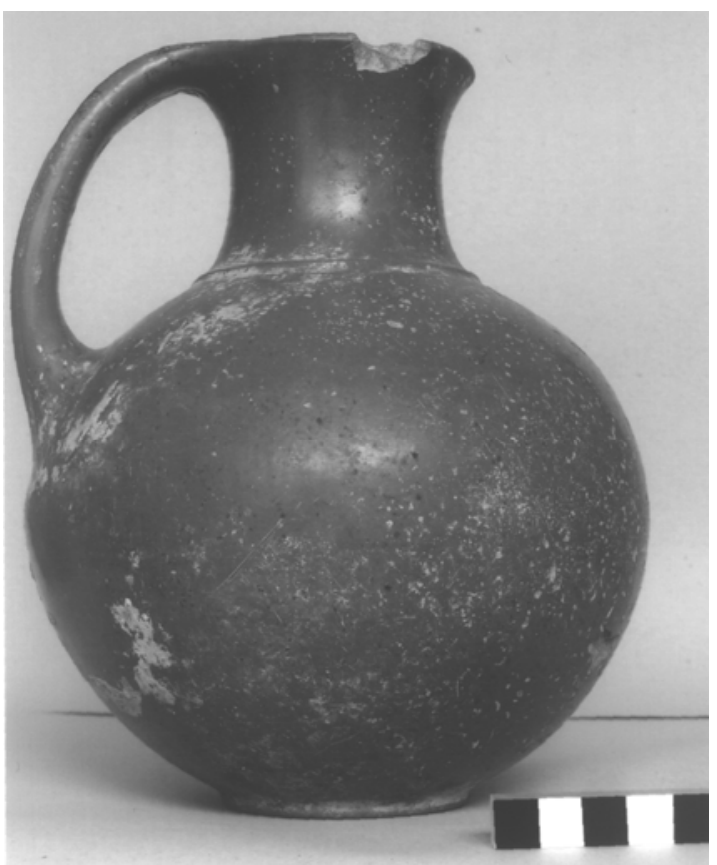

a

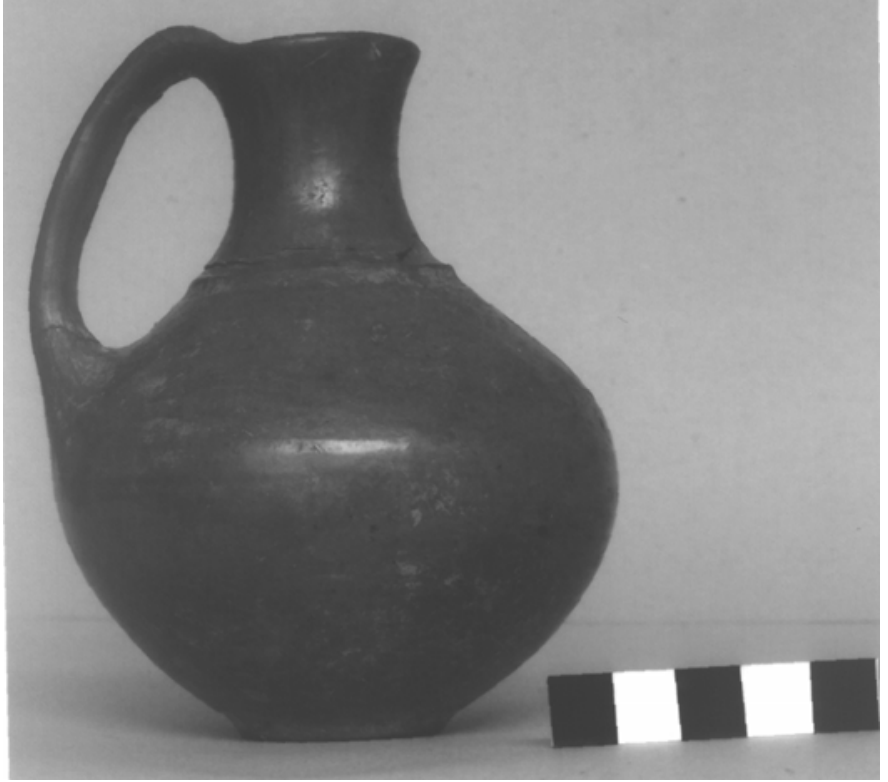

Plate IV 
Urartian Red Burnished Pottery From Diyarbakır Museum

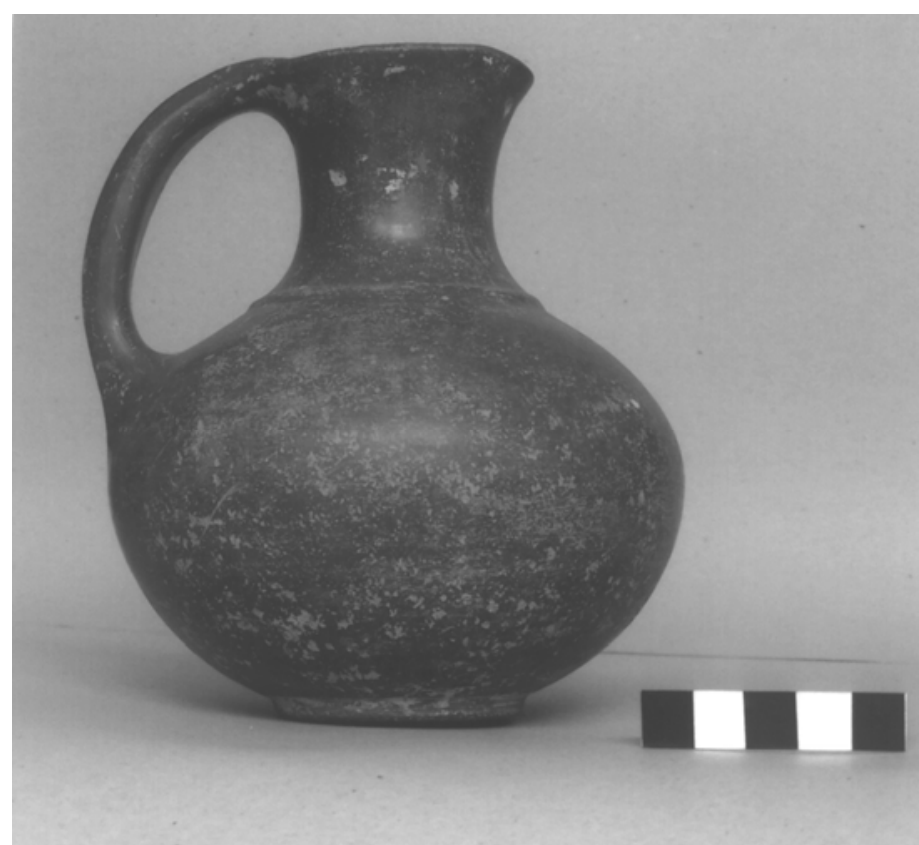

a

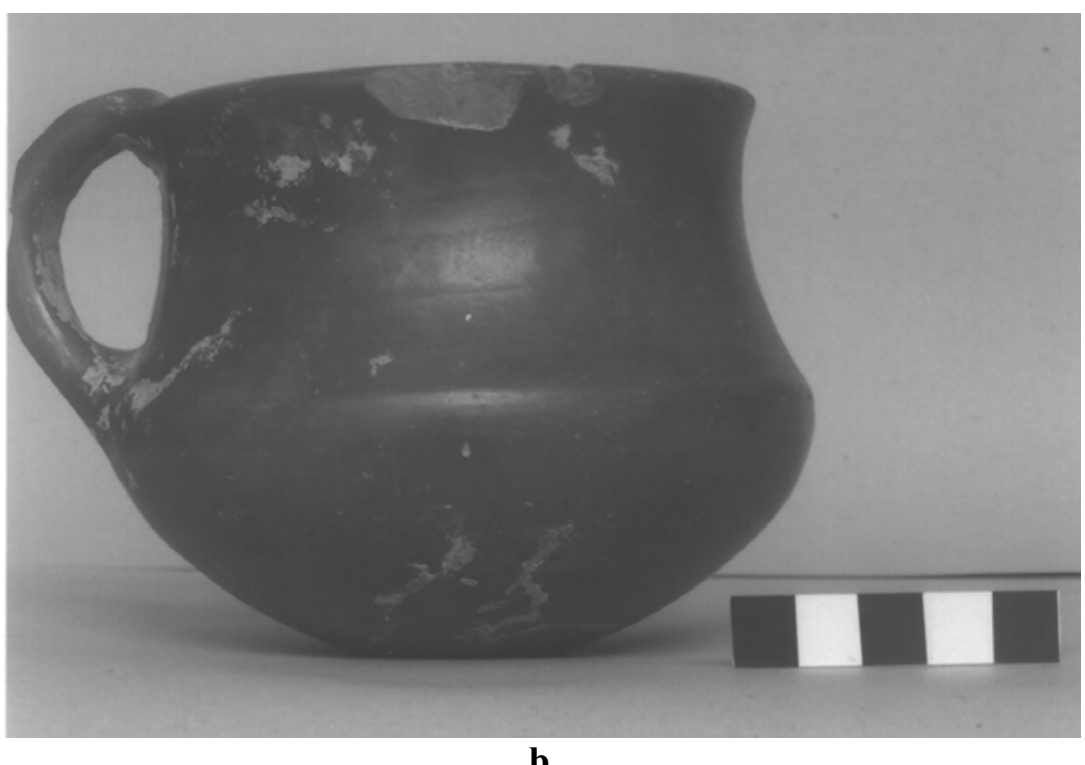

b

Plate V 


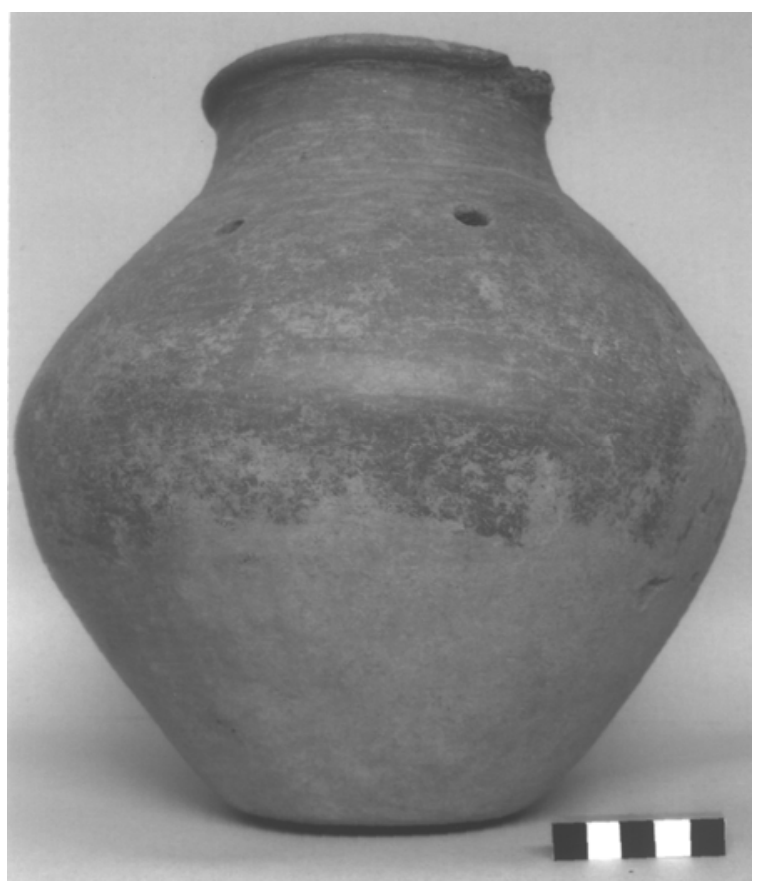

a

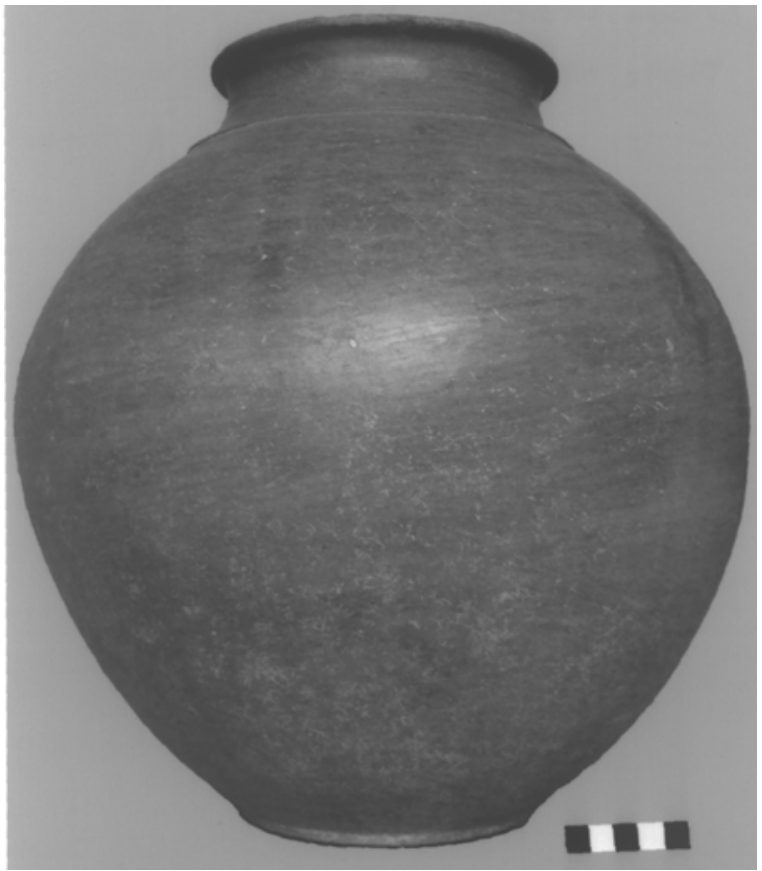

b

Plate VI 
Urartian Red Burnished Pottery From Diyarbakır Museum

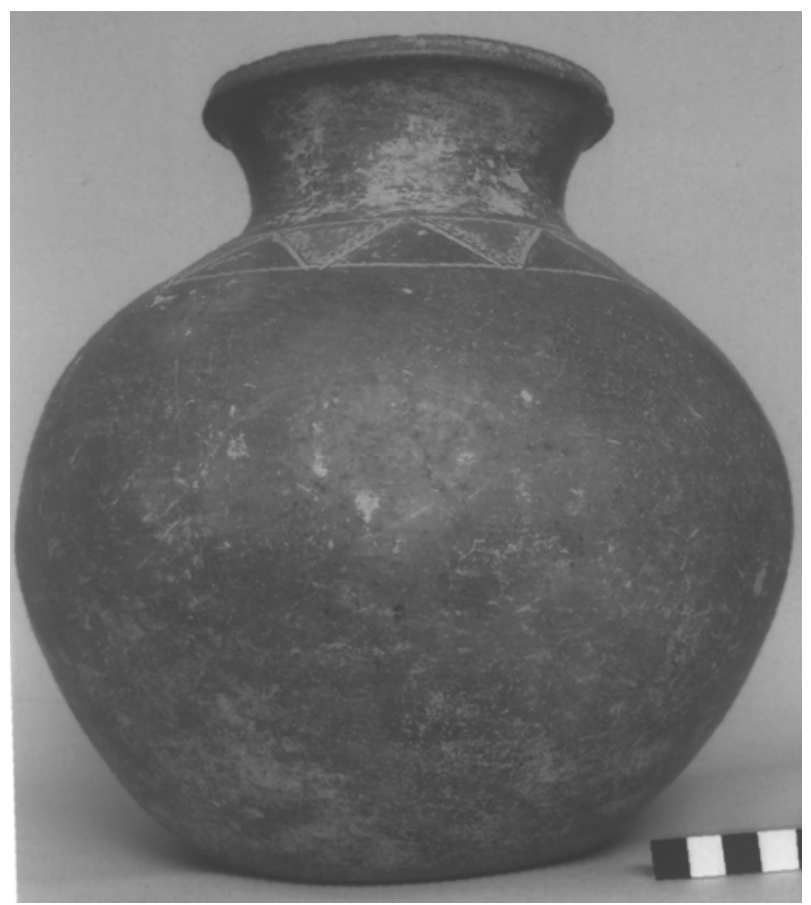

a

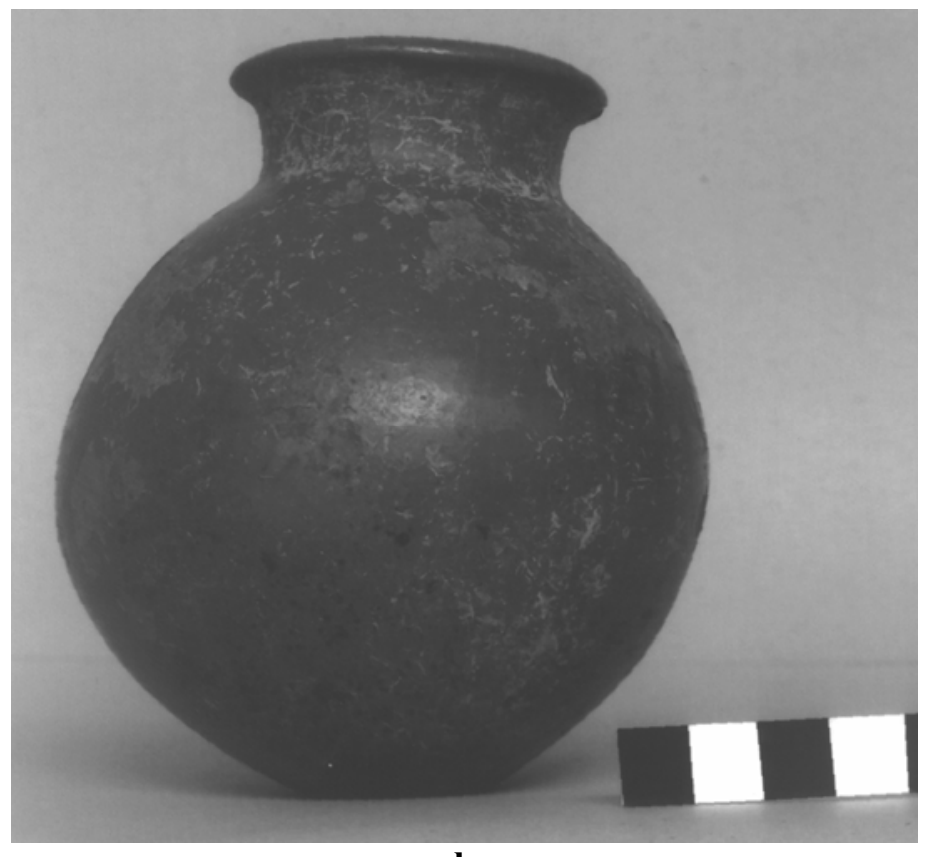

b

Plate VII 